\title{
Human Capital of Mexican Return Migrants
}

\author{
Capital Humano de los Migrantes de Retorno Mexicanos \\ Blanca Josefina García Hernández ${ }^{a}$, Gerardo Suárez Barrera ${ }^{b}$
}

\begin{abstract}
:
This proposal is the result of an investigation carried out among a group of undocumented Mexican migrants, located in the state of Texas, United States, and who, due to their immigration status, constitute a vulnerable group with the latent risk of being deported to their country of origin (COO).

The purpose of the study is to offer a characterization of the Human Capital of migrants, based on information that includes age, gender, schooling, origin, family dependents, length of stay in the country of residence (COR), immigration status, occupation, health conditions, English proficiency, labor experience and skills. This profile makes it possible to identify the entrepreneurial potential that migrants can offer in the event that they return to their $\mathrm{COO}$ and to have the possibility of designing strategies and public policies that allow this group of people to be reintegrated into sustainable economic activities.
\end{abstract}

Keywords:

International migration, Human Capital, Entrepreneurship

\section{Resumen:}

La presente propuesta es el resultado de una investigación realizada entre un grupo de migrantes no documentados mexicanos, localizados en el estado de Texas, Estados Unidos, y que debido a su condición migratoria constituyen un grupo vulnerable con el riesgo latente de ser deportados a su país de origen (PDO).

El propósito del estudio es ofrecer una caracterización del Capital Humano de los migrantes, a partir de información que incluye edad, género, escolaridad, procedencia, dependientes familiares, duración de estancia en el país de residencia (PDR), estatus migratorio, ocupación, condiciones de salud, dominio de inglés, experiencia laboral, forma de trabajar, habilidades y hábitos de vida. Dicho perfil permite identificar el potencial emprendedor que los migrantes pueden ofrecer en caso de que regresen a su PDO y tener la posibilidad de diseñar estrategias y políticas públicas que permitan reinsertar a este grupo de personas en actividades económicas sustentables.

Palabras Clave:

Migración internacional, capital humano, emprendimiento

\section{Introduction}

The conditions that migrants face on a day-to-day basis is a relevant topic that must be included in the political agenda of all countries. The case of Mexican migrants living in the United States who do not have the legal documentation proving their stay in that country, puts them in the latent possibility of being deported to Mexico; therefore, it is an issue that requires attention where it is necessary to provide solutions viable in the short term.
This proposal is part of a project through a qualitative approach, with the objective of identifying the bases that would allow the design of future strategies to incorporate these migrants into economic activities. In this context, the project begins with identifying the characteristics of Mexican migrants through the compilation of information about the characteristics of Human Capital that constitute the foundations of future entrepreneurial activities.

Unlike many quantitative studies that are frequently published by Mexican official entities, this proposal

\footnotetext{
a Foreign Trade research professor at Universidad Autónoma del Estado de Hidalgo, https://orcid.org/0000-0002-1257-922X, Email: bgarcia@uaeh.edu.mx

${ }^{\mathrm{b}}$ Foreing Trade research profesor at Universidad Autónoma del Estado de Hidalgo, https://orcid.org/0000-0003-1868-3658, Email: gerardo_suarez@uaeh.edu.mx
} 
incorporates aspects that can only be obtained through an inductive and interpretive exploration; product of the interaction and direct observation with the central figures of the research. It also considers the environment in which they are located, since it allows to closely observe their perceptions, beliefs, fears, experiences and particular situations that they experience being away from their country of origin. This research work considers primary sources from a real environment, where an initial coding with theoretical bases is elaborated, that also aims to reflect integrally the contributions of the interviewees. Bibliographic review is also considered to compare the results obtained and to give an orientation to the structure of the research. In addition, the review and approval of experts on Migration and Entrepreneurship has also been provided. The obtained results offer specific information about the profile of returning Mexican migrants and their entrepreneurial potential.

\section{Literature review}

International migration can be approached from two basic perspectives: Macro or Aggregate, and Micro perspective. The first one is based on studies related to the physical and socioeconomic population environment, Therefore it is objective. The second one focuses on a cognitive philosophy that uses the of migrants subjective perceptions. It is important to consider both approaches in order to obtain a comprehensive context.1,2

In this way, it is pertinent to address the Social Capital Theory, which distinguishes a set of intangible assets in families and communities that help promote social development among young people, in order to create a link with non-governmental social networks and institutions, whose purpose is to access a series of benefits that, over time, may favor the conditions of leaving their communities of origin, creating social capital. $3,4,5$

On the other side, the Theory of Transnationalism, considers migration as the process through which individuals maintain social, economic, cultural and political relations between their place of origin and their destination, and it includes several practices such as labor markets, goods and services trade, besides to the continuous circulation of people, money, goods and information, that leads to the rising of a transnational community. 6,7

Migration has a transcendental impact in transnational contexts due to its volume, the macroeconomic importance of remittances, and their contribution to the country of origin $(\mathrm{COO})$ development. 8,9
Based on same approach, the Human Capital Theory, recognizes that knowledge provides individuals with cognitive skills that may help them to become more productive in the future and with the possibility of developing an efficient potential activity. In addition, formal education provides individuals with explicit knowledge that enhance the individuals abilities. $10,11,12,50$

The Theory of Transnationalism is especially relevant to approach the fundamentals on the formation of migrant entrepreneurs, since at first instance migrants send money to their relatives, but in a second stage it becomes evident the presence of businesses created with capital coming from migrant population, which, finally, become ethnic economic enterprises, which arise from the nostalgia of migrants in the country of residence (COR) and the relationship with their country of origin (COO). 13,14

The concept Return Migration refers to the displacement of people who decide to return to their country of origin after having stayed in a country of residence abroad for a significant period of time. To this concept, Recaño adds that the country of origin must be specified as the place of birth. On the other hand, it is possible that the migrant has made international migratory circuits, that is, with stays between two or more countries lasting more than six months. Cerase and Gmelch, agree that migrants return to their $\mathrm{COO}$ after a working period of 2 years, in which they suffered many adversities and were unable to adapt to the environment, and therefore, this return may be voluntary. 15-24

However, it is the forced return that perhaps generates the highest number of migrant returns, which is fostered by not having the documentation that proves their legal stay in the COR. 8

Regarding the main destination of Mexican migrants in the United States, it varies depending on the condition this group of people face. On the one hand, there are migrants detained after crossing the border, most of whom are deported from Texas (38\%) and Arizona (31.2\%), while illegal migrants with residence for more than one year, preferably remain in California (67.3\%). 25

Voluntary returns share three characteristics: (i) they have increased because of a more effective border control, (ii) there is a South-North downward flow, and (iii) there has been a sharp decrease in migratory dynamics, not only in the South-North flow, but also in the North-South, since the rate of return of Mexicans from the United States increased by around 73.4 per thousand inhabitants during the last 7 years. 8,26 
Although some return migrants are influenced by exogenous forces that condition their performance, there are studies that conclude that their sociodemographic profile also exerts a relevant influence. This group is made from a $48.7 \%$ of people between 15 and 29 years old; $48.1 \%$ of 30 to 49 years, and $3.2 \%$ from people over 50 years old. $91.1 \%$ are men and $8.9 \%$ women, whose work occupation is mainly in the services sector $(35.5 \%)$; construction (20.1\%); agricultural (14.8\%); industry $(12 \%)$; professionals or technicians $(11.5 \%)$ and merchants (6\%). 25,27

The above mentioned is especially important, since individual attributes are determining factors that influence the probability that people may obtain information to aknowledge opportunities. With regard to obtaining information, the factors are i) life experiences; ii) social networks; and iii) information search. Regarding the recognition of opportunities, the following are considered: i) absorption capacity and ii) the cognitive process, made up of intelligence; perception ability; creativity and the inability to see risks. All these elements are essential for entrepreneurial activity to emerge. 28

Based on the above stated, it is possible to establish three propositions:

Proposition 1. Mexican return migrants have low qualifications and limited possibilities of increasing their Knowledge level. Of the total of return migrants, only 2.3 percent have a bachelor's degree, 18.1 percent complete or incomplete high school; 37.6 percent high school and the remaining 42 percent have not completed high school. In addition, the average number of years of study is 9.4 years. The information allows corroborating the statements made by Noin and Chadndna, regarding the low qualification of migrants, as well as their economic motivation. 25,29,30

In the case of Mexican migrants, the main barriers to study are financial, academic, legal, the association with their work and family responsibilities; as well as the lack of information to obtain financing. The consequence of these difficulties of access to education for Mexican migrants was an educational crisis. While from 1985 to 2005, the Caucasian population increased the number of students pursuing higher education from $24 \%$ to $34.1 \%$; African Americans from $12 \%$ to $17.5 \%$; and Hispanics $11 \%$; Mexicans over 25 years of age with a university degree are only $2.5 \% .31$

Proposition 2. Entrepreneurial Mexican return migrants are people with a sociodemographic profile made up mainly of people between 15 and 29 years of age, male, with 9.4 years of studies and whose main motivations are to meet with their family, work and establish a business; driven by needs and not by opportunities. The productive sectors where Mexican return migrants mainly work are services (35.5\%), construction (20.1\%), agriculture $(14.8 \%)$, industry $(12 \%)$, professionals or technicians (11.5\%) and merchants (6\%). 25

Previous studies have shown that among the main motivations that Mexicans have to become entrepreneurs are i) financial independence; ii) increasing family income; iii) having challenging incentives; iv) family support; v) implementing a business career; vi) establishing alliances with friends to create businesses and vii) as a hobby. 32

Proposition 3. Return migrants constitute the Human Capital to start a new business, basing their proposals on the experience, knowledge and skills previously acquired. Among the skills developed by migrants during their stay in the country of residence are the use and handling of manufacturing machinery without a high degree of technology, and a medium knowledge of the English language stands out. Additionaly, the experience acquired to make use of services is also noteworthy. such as portfolio investments, insurance and retirement savings funds, as well as mortgage services and awareness of a culture of equity investment. The business profile or these migrants is mainly concentrated in activities in the service sector and food production, trade and professional, scientific and technical services. 33

\section{Ellaboration}

The research work has an inductive exploratory approach, based on social constructivism (interpretivism), to understand the particularities of the phenomenon, which are not possible to measure, where the perception of individuals has a multi-level mechanism and is therefore subjective, from the perspective of the participants in a natural and contextual environment. Without forming a mixed investigation, figures are also offered, which are included as a reference to the findings without performing making a deep quantitative analysis. 34,35,36

\section{The proposal considers five stages:}

The first stage of the research is aimed at identifying the sociodemographic characteristics of Mexican migrants, for this purpose, a documentary review will be carried out based on the Grounded Theory method (Glaser and Strauss, through a documentary review on migration, 
Return migration, Mexican return migrants and entrepreneurial Mexican return migrants. 37

The second stage consists of performing interview sessions that allow identifying the motivations for which potential forced return migrants leave Mexico and go to the United States; the influencing factors that attract them to that country; their sociodemographic profile; their motivations for becoming entrepreneurs; the skills, knowledge and preferences they possess to become entrepreneurs.

Accessing to the interviewed population, which lacks documentation to guarantee their legal stay in the United States, represents a complicated task. On the other hand, the resources and time available to carry out the research condition the number of surveys to be applied, so that application is subject to the appearance of theoretical saturation, once all the codes of the studied population are look at the statistical sample. 22 interviews were conducted. $38,39,40,41,42$

The information was collected in person, in Spanish and / or English through semi-structured interviews with Mexican migrants who do not have documentation proving their legal stay in the country of residence, who could potentially return to Mexico, and whose The location was the state of Texas, being one of the states with the highest concentration of Mexican migrants, as well as Arizona and California. Recordings previously authorized by the interviewees were used. 27

The interview process allowed making observations about the environment in which people live, as well as the attitudes they have and getting the possibility of recognizing unexpected situations. In this way, credibility will be obtained by recording the perceptions, experiences, reconstruction of cases or events of the people interviewed. 37,40

The third stage consists of analysing the information collected through the use of Atlas-TI software, version 8.

To obtain the best results in the analysis of information collected through interviews, the following steps in accordance with the recommendations of Gioia, Corley and Hamilton and Van Rijnsoever were carried out:

- Recordings transcription to text, in DOC and PDF format to obtain information as close as possible to the lexicon used by the interviewees, that is, paraphrasing the interviews in order to encode them.
- Identification in the texts of the interviews of the main first-order codes, those that were provided by the interviewees.

- Identification of the theoretical saturation at the time when there was no longer new information to discover and codes or citations no longer emerged, translated as analysis units

- Sub-codes or categories were obtained from the first codes, with a theoretical foundation in relation to the initial code.

- Once the first-order codes were obtained, a list of second-order codes was drawn up, which adhere to the content established in the theoretical framework. The codes were reviewed and validated by experts on the subject.

The fourth stage provides the found results, and finally the conclusions are shown. 41,43

\section{Results}

The interviewed, undocumented Mexican immigrants, with residence in Dallas, Texas, make up a Human Capital with the following characteristics:

Gender. Of the undocumented migrants interviewed in the city of Dallas, Texas, fifty-seven percent were women and forty-three percent were men. Age. Fifty percent of the migrants interviewed were from 31 to 45 years old; thirtysix percent were from 46 to 60 years old and fourteen percent were from 16 to 30 years old.

School Education. The highest percentage of schooling $(22.73 \%)$ is shared by migrants who have completed primary and secondary education. The second place and in the same proportion $(13.64 \%)$ it is held by migrants who did not finish primary and high school studies and those who do not have studies. Finally, migrants with unfinished secondary education, bachelor's and unfinished bachelor's degrees, share the lowest percentage (4.55\%).

Place of origin. The interviewed migrants came from the state of Guanajuato, secondly from Querétaro; San Luis Potosí, Jalisco; and with the same frequency those from Tamaulipas, Nuevo León, Michoacán, State of Mexico, Coahuila and Chiapas.

Family dependents. Families with three dependent children make the highest percentage of family composition, although it is interesting to note that ten percent of families have ten dependent children and the same percentage is represented by families without children. Likewise, it can be seen that in ten percent of households the head of the family is a woman who does not have a partner. On the other hand, there is the case 
of a man who reports having two partners. The rest of the families are made up of couples of a man and a woman, although there are special situations, in which cases of single mothers or men with two families are considered:

"...I've got my daughters but I don't have a partner, I'm on my own" (María, undocumented migrant, 45 years old) "...I have two children but I don't have a partner..." (Irma, undocumented migrant 56 years old)

"...I have two kids, a wife back in México and a partner here in the U, S...." (Rigoberto, undocumented migrant 43 years old)

Length of stay. The highest incidence corresponds to migrants who have stayed for twelve years in the country of residence; in second place and with the same percentage, those who have stayed for 10, 15, 20 and 23 years; while in third place, the proportion is shared by migrants who have a stay of 17, 18, 19, 21 and 41 years. Only one migrant without documentation reports having made multiple stays for less than one year, for 42 years and has not obtained residency or US citizenship.

"...I only come eight or seven months and then go back to my family, I never stay here for years. Its less good leaving your family alone..." (Rubén, undocumented migrant, 56 years old)

Migratory status. Eighty-six percent are migrants without documentation; while nine percent are residents; and five percent affirm that due to circumstances such as sexual abuse and family violence, the State has protected them and, as a result, they are in the process of obtaining their residence.

"I have had family problems, but they do not force me to return to Mexico, on the contrary, they have helped me to obtain residency here. Due to family violence I asked the United States for protection and they helped me obtain papers. Also because my ex-husband took advantage of my daughter... and that has helped us to be well here..." (María, migrant without documentation, 45 years old).

Current occupation. The main activity to which women are engaged is cleaning houses and offices, and in many cases is an activity that is combined with childcare and housekeeping. With respect to men, the main activity they carry out is related to electrical, mechanical, construction and gardening installations, although they can also combine two or three activities either simultaneously or periodically. There is also a nearly five percent unemployment rate.

Health. Among the health problems that Mexican migrants face are overweight, diabetes, kidney failure and some cases of diseases that require specialized surgeries. In most cases they do not refer to illnesses that may require hospitalization, which is seen as an advantage, since by not having social security, medical attention is very expensive and in many cases inaccessible to them.

"...In Mexico there is obesity too. Here, normally the majority of Hispanics, specifically Hispanics and the African-American race, are more over weighted..." "(Rosario, migrant without documentation, 35 years old). "... I had a brother, a little while ago we went to bury him, he told me he had diabetes and they were doing dialysis and every so often he told me: the day I die, I want you to take me to Ocampo!..." (Francisco, resident, 63 years old).

"... My hand hurts and I need insulin and when I go to get it, they don't give it to me because I don't have that program..." (Dominga, undocumented migrant, 49)

"... my brother broke his hand from jumping over the fence to get the last things he had left ... he is very sick and can no longer be there, and here it makes us sick" (Dominga, migrant without documentation, 49 years old).

"... I have a tumor on my head. The other time they detected it and I was hospitalized...studies and everything cost me 70 thousand pesos and it was what I had, the only thing. So I came here right now, to collect some money and to see if I can have an operation, so if I collect a little money, then let's see if I can have an operation "(Rubén, migrant without documentation, 56 years old).

"... I thank God, that I have never gotten sick and here I have just gone to the Rangers hospital that I have here,... twice nothing more and here they treat one very well, I have never gotten sick badly, no " (Rigoberto, migrant without documentation, 43 years old).

"... Right now my brother is sick and right now he is working... I don't send him much because, as I said, the expenses of being here are heavy and as someone who is a migrant without documentation does not earn as much money, that is to say, the least, so there is not so much money "(Irma, migrant without documentation, 56 years old).

Language. Language fluency is perhaps one of the problems with the greatest impact on migrants because it limits their communication and reduces the chances of finding a good job. One hundred percent of those interviewed indicate that they do not speak it or speak it very little.

Work experience. Migrants have an average work experience of 11.75 years. Among the economic activities to which they have been dedicated, the cleaning and maintenance of buildings top the list; automotive mechanic; cook and kitchen assistant; agriculture, 
gardening, and plumbing. As can be seen in Graph 8, there are activities that reflect a similar percentage, although to a lesser extent, such is the case of trash collection; bakery; brickwork; washing and ironing; electricity; trade and retail sales; and livestock.

"Well, I am working for senior citizens, which is like going to shower them at home and, housekeeping, yes, cleaning houses. That's my job. And well, I have been working on it for many years, I have been working on it for 10 years" (María, migrant without documentation, 45 years old).

"Yes, the cleaning of houses and offices" (Rosario, migrant without documentation, 35 years old).

“... In mechanical workshops" (Mr. Álvarez, migrant without documentation, 40 years old).

"House cleaning work" (María, migrant without documentation, 55 years old).

"10 years in a restaurant" (Francisco, resident, 63 years old).

"I grow corn and beans, and barley and wheat. It is what is grown there. There it is very good to grow corn and beans ... I have about 30 hectares, nothing but cultivation" (Francisco, resident, 63 years old).

"Putting trash containers, and selling trash. In that I worked for about 14 years, with a truck... I have the commercial license to be here..." (Carlos, migrant without documentation, 51 years old).

"I have worked here but in factories. In Mexico I worked in a bakery. I used to..., it was at the counter, or in the back, placing the bread' (Claudia, migrant without documentation, 45 years old).

"House remodeling" (Alberto, migrant without documentation, 39 years old).

"I prepare vegetable for salads, cleaning buildings" (Ofelia, migrant without documentation, 29 years old).

"Selling popsicles, chopping nopales, that's what I know, why should I be ashamed? Making tortillas, what else? I even forgot... A little while ago, I put the tomato in the machine, since then I no longer... I hurt my hand" (Dominga, migrant without documentation, 49 years old). "House cleaning. As a housewife" (Angélica, migrant without documentation, 36 years old).

"At the age of 13 I already dedicated myself to mechanics as I have done until now" (Rigoberto, migrant without documentation, 43 years old).

"I have only ironed and washed clothes" (Francisca, migrant without documentation, 30 years old).

"I am an electrician. But I can do plumbing, roofing, flooring, welding, tape, everything that is construction" (Jesús Antonio, migrant without documentation, 35 years old).

"Cleaning jobs, I only know how to cook and clean" (Irma, migrant without documentation, 56 years old).
"I worked, I learned to use the machine, to cook barbecue, menudo, birria, and chicken and pork tamales. After there, I went into a dessert shop" (Maricela, migrant without documentation, 30 years old).

"I have only worked cleaning offices, and I took care of children" (Fabiola, migrant without documentation, 52 years old).

"Moving, cutting trees, yards" (Norberto, migrant without documentation, 44 years old).

"My job was cement... I have sheep, I take care of sheep, that is, mine, but I have to work. Because if I go and stay there, it ends and we are going to come again... I arrived in Florida at the pinch of tomato... yarn and plumbing" (Rubén, migrant without documentation, 56 years old).

"I worked 15 years as housekeeping and I no longer work" (Marta, migrant without documentation, 55 years old).

Work ethics. Mexican migrants reflect an attitude towards work of perseverance and continuity. Their desire to improve guides them to do hard and varied work, since their pressing needs force them to seek various alternative occupations and within their effort to maintain their occupation, they acquire new knowledge. Once they are located in a different country of residence, household responsibilities are shared between men and women to achieve a shared benefit.

"...Well, but here it is better because they respect much more the worker, safety and all that, yes. Sometimes, for one, they say, do not expose yourself so much to the heat, but sometimes one already comes, how do you say it? He already comes as a hardened man to work, he is no longer interested in that, the heat, yes, yes affects, right?" "... I worked in Mexico for some time. My income was therefore very low, you can see that I came from town, but I also worked in the supply center and well, with the life that we led in Querétaro, I had to emigrate from Querétaro to the Federal District, and from the Federal District I came to here. Supposedly one comes for the dollars" (Gabino, migrant without documentation, 42 years old).

"I work hard in the fields and sometimes without pay" (Francisco, resident, 63 years old).

"In Mexico, who knows that, doesn't teach. Not here, here anyone teaches you straight away and very quickly you learn everything. I went to my job school a bit, but years of school to get licenses, I have licenses for what I do. Perhaps a little more true, but even so I didn't miss school here to be able to know all that "(Jesús Antonio, migrant without documentation, 35 years old).

"Sometimes I work in factories in Querétaro, here I work there and take a job at Seven, well, everything, yards, 
plumbing, whatever it takes" (Rubén, migrant without documentation, 56 years old).

"Well, really the payment is very little, it is working all day for a minimum amount ... because here in the United States it is such a life, we men and women work, but the children go to be cared for in different houses" (Fabiola, migrant without documentation, 52 years old).

Skills. Among the skills that Mexican migrants possess which they have developed through their work experience - are cleaning houses and buildings; food preparation and processing; automotive mechanic; agriculture and gardening; masonry and construction; electricity; handling, storage and loading of food; driving vehicles; bakery; care of the elderly; hair styling and cutting; Childcare; moving management; cattle raising; sale of pet, plastic and glass; making piñatas and party supplies.

Life habits. The life habits of migrants refer to the way they usually live in their $\mathrm{COO}$, and the form this influences their way of living in the country of residence, within the new way of life, the use of the car to move stands out, although it replaces the habit of walking.

Constantly working without considering space to rest; trying to live better, which translates into having a hectic life, aware of time and being up to date with the payment of services; the use of technology such as the cell phone, which has led to a lack of communication, which in the opinion of some interviewees, contributes to disintegrating the family and polarizing human relationships.

On the other hand, there are migrants who want to transfer their way of life from their country of origin to the country of residence. This includes bad habits, such as littering in the street or committing crimes through illicit activities related to drug trafficking, which for some of the interviewees it translates as an invasion.

"... One does not walk. But the car, right?" (Rosario, migrant without documentation, 35 years old).

"... one is working all the time ... from dawn to dusk" (Mr. Álvarez, migrant without documentation, 40 years old).

"I don't know why one insists on wanting to live better, but nothing is better neither here nor there, because it is almost the same, because here you go to the pure clock, to the pure move there, that it is time to pay the telephone because they cut it off, gas, water, electricity, insurance..." (Dominga, migrant without documentation, 49 years old).

"Our people do not accept the conditions here, but many people come from Mexico who are drug traffickers, who make their own laboratories, here, many poorly educated people ... for example throwing garbage, garbage is not thrown here, and the Mexican arrives and throw away your trash "(Jesús Antonio, without documentation, 35 years old).

"... the Mexican not only comes to work, but they already come to ... they want to invade this country, when it is not ours and this ... I as a Mexican do the same, unfortunately our people are like that" (Jesús Antonio, migrant without documentation, 35 years old).

"Here I have had to see...you sit down to eat with someone and just the phone, people don't even talk anymore... Sometimes they are sad too, they say yes, there is a better side to living, but also like the family is leaving ending, here. Everyone in a hurry, here it is not like in Mexico. It is difficult" (Marta, migrant without documentation, 55 years old).

\section{Conclusions and discussion}

1. The results of the research carried out indicate that there are a greater number of Mexican migrant women than men. What may be the product of the location, temporality or specific conditions in which the interviews were carried out, therefore, this point is left without discussion.

2. The highest percentage of Mexican migrants are between 30 and 49 years old.

3. The level of education is lower than what official sources reflect, since only $27.28 \%$ of migrants have completed primary school, while those who completed secondary school represent $36.37 \%$. However, it is pertinent to underline that the percentage of migrants who have not completed their primary education is $13.64 \%$, the same percentage as that of migrants who did not complete high school education and those who do not have studies. Finally, migrants with a bachelor's degree and an unfinished degree represent $4.55 \%$ each.

4. It is confirmed that the state of Guanajuato is the main source of Mexican migrants to the state of Texas, following in order of importance the states of San Luis Potosí and Querétaro. While the northern states of Mexico such as Tamaulipas, Nuevo León and Coahuila represent a region that, given their geographical location, contribute a significant percentage to migration from South to North.

5. It is distinguished that seventy percent of Mexican migrant families have between three and two dependent children. This figure increased 15 percent in 
2018 compared to 2016 . The descendants of migrants can make up the Human Capital for future ventures.

6. The length of stay of migrants ranges from 10 to 41 years, without having obtained residency or citizenship in the United States, and therefore the permanent risk of being deported to their $\mathrm{COO}$ is latent.

7. Official figures are confirmed that fifty percent of Mexican migrants living in that country do not have documentation proving their legal stay.

8. Mexican migrants without documentation are mainly dedicated to offering services, since due to their immigration status, they do not reflect ownership of their own businesses and in their entirety they refer to offering their services to other people who do possess citizenship or residence. The activities to which they are dedicated in the case of women is cleaning buildings or private houses and caring for children or the elderly. In the case of men, they offer their services in electricity, mechanics, construction and gardening.

9. Unlike the figures reflected by CONAPO-BBV, this research indicates that one hundred percent of migrants without documentation lack health services and only access this type of services in a particular way, although it is corroborated that the chronic diseases that affect this type of people are overweight, obesity, diabetes and kidney disease. 27

10.The affirmations of Pío and Ho, regarding that one of the biggest problems that undocumented migrants have is their lack of command and use of English to communicate are confirmed, and those represent the main barriers to carry out work activities and integrate into COR society. 44,45

11. The profile of Mexican migrants who can potentially return to their $\mathrm{COO}$ indicates that their professional experience is broad and diverse, with an average of 11.7 years, in multiple economic sectors, so their potential as entrepreneurs is broad since they are more likely to establish their own businesses. On the other hand, they have skills, experience, ideas, technology and knowledge, which they are willing to share with their compatriots so that they in turn acquire new skills and entrepreneurial experience. In this way, the areas of opportunity that are identified to start new businesses are mainly: cleaning and maintenance of buildings, automotive mechanics, kitchen and kitchen helper, agriculture; gardening; masonry and plumbing. Although these activities are common in their COO, they can be improved through the use of new methodologies and technology that facilitate the tasks to be carried out.

12. Although the ethnic roots of Mexican migrants who can potentially return to their $\mathrm{COO}$, provide them with a cultural identity, it is through their experiences and experience in a different country that strengthens their perseverance and modifies the way they live and work. , since the responsibilities in the couple that make up the home are shared. Thus, the statement of Pio is confirmed, who mentions that migrants are willing to modify their way of life with the ultimate aim of improving their income. In this way, a Human Capital is being formed that is capable of adapting to the opportunities that appear throughout their lives, so it is possible that they carry out activities as employees or start their own business. 44,46

13. Authors such as Chrisman, Bauerschmidt and Hofer, state that skills can be developed in various contexts, highlighting communication, finance, interpersonal, administrative, manufacturing, marketing, organizational, labor and technical relationships, however, in the In the case of Mexican migrants, it is necessary to be very specific in recognizing the skills they have developed or acquired, since the research carried out shows that the skills of migrants are mainly focused on offering services such as cleaning houses and buildings, preparing food, mechanics, electricity, gardening and masonry, therefore, thinking about designing strategies to carry out other more complex or sophisticated activities, could be a mistake. On the other hand, the statement by Kshetri, Rojas-Torres and Cardona regarding that the skills, experience, ideas, technology and knowledge of return migrants provides the opportunity for them to share new skills with their nationals and acquire entrepreneurial experience, it is an opportunity that may arise in the future to form entrepreneurship support networks.47,48

14.According to Kenney, Breznitz, and Murphree, the return of migrants generates a virtuous circle of technological entrepreneurship, creating a new way of life and a renewed vision of the world. Within the new way of life of Mexican migrants, the use of the car to get around and adjust to the infrastructure they have stands out, although it replaces the habit of walking; constantly work to achieve goals; trying to live better, which encourages migrants to improve their living conditions permanently; optimize time; be aware of the importance of paying for services and contributions; and make the most of the use of technology. 49 
The results obtained in this research are offered to design future strategies and public policies that allow incorporating this group of people into sustainable economic activities that reactivate the local and regional economies of Mexico. Failure to take into consideration the characteristics of the Human Capital of Mexican migrants condemns public strategies and policies to failure.

\section{References}

[1] Franco, L. Migración y remesas. Pachuca; Editorial UAEH; 2012.

[2] White, M. Urban renewal and the changing residential structure of the city. Chicago: Chicago Community and Family Study Center; 1980.

[3] Arango, J. La explicación teórica de las migraciones: luz y sombra. Migración y desarrollo; 2003; 1(1), 1-30.

[4] Durand, J., y Massey, D. Clandestinos. Migración México - Estados Unidos en los albores del siglo XXI. Zacatecas: Porrúa; 2003.

[5] Loury, G. A Dynamic Theory of Racial Income Differences. En P. Wallace, y L. Mond, Women, Minorities, And Employment Discrimination. Lexington, MA: Lexington Books; 1977.

[6] Bobes, C. Los tecuanes danzan en la nieve/ contactos trasnacionales entre Axochiapan y Minnesota. México: FLACSO; 2011.

[7] Portes, A., Guarnizo, L., y Landolt, P. The study of trasnationalism: Pitfalls and Promise of an Emergent Research. Ethnic and Racial Studies; 1999; 217-237.

[8] Durand, J. Nueva fase migratoria. Papeles de Población; 2013; 19(77), $83-113$.

[9] Lozano, F.Bringing it back homr: remittances to mexico from migrant workers in the United States. San Diego: Center for U.S. _ Mexican Studies; 1994. Obtenido de http://ccis.ucsd.edu/xpcontent/uploads/WP_99.pdf

[10] Schultz, T. Investment in man: An economist's view. The Social Service Review; 1959; 33(2). 69-75.

[11] Becker, G.S. Human capital. Chicago: The University of Chicago Press; 1964.

[12] Mincer, J. Schooling, Experience and Earnings. New York: Columbia University Press; 1974.

[13] Faist, T. The volume and dynamics of international migration and trasnational social spaces. London: Oxford University Press; 2000.

[14] Pardo, A. Migración internacional y desarrollo. Aportes desde el trasnacionalismo. Revista de Estudios Sociales de la Universidad de Los Andes; 2015; 39- 51

[15] King, R. Problems of return migration: case study of Italians returning from Britain. Tijdschr; 1977; 68(4), 241-245.

[16] Pascual de Sans, A. Connotaciones ideológicas ene 1 concepto de retorno de migrantes. Revista de Sociología; 1983; 20, 62-71.

[17] Recaño, J. Las migraciones internas de retorno en españa. De la óptica individual a la dimensión familiar. Revista Sociológica; 2010; 95(3), $701-729$.

[18] Bustamante, J. El marco teórico-metodológico de la circularidad migratoria: su validez empírica. Revista Sociológica de pensamiento social; 1997; 2, 77 - 119 .

[19] Cassarino, J. Theorising Return Migration: The Conceptual Approach to Return Migrants Revisited. International Journal on Multicultural Societies; 2004; 6(2), 253-279.

[20] Co, C., Gang, I. y Yun, M. Returns to Returning. Journal of Population Economics; 2000; 13(1), 57-79.
[21] Cerase, F. The Italian Experience in Emigration. International Migration Review; 1967; 1(3), 67-74.

[22] Cerase, F. Nostalgia or disenchantment. En S. Tomasi, y M. Engel, The Italian experience in the United States. New York: Center for Migration Studies; 1970; 217-239.

[23] Cerase, F. Expectations and reality: a cese study of return migration from the United States to Southern Italy. International Migration Review; 1974; 8(2), 245-262.

[24] Gmelch, G. Return Migration. Annual Review of Anthropology; 1980; 9, 135-159.

[25] COLEF - SEGOB. Encuesta sobre migración en la frontera norte de México. Informe de Resultados 2014. Tijuana: Colegio de la Frontera Norte, A.C.; 2016.

[26] Calva, L., y Coubès, M.-L. Desaceleración de la dinámica migratoria: descenso generalizado de los flujos de salida y de retorno de migrantes mexicanos; 2016.

[27] CONAPO, Fundación BBVA Bancomer, B. R. Anuario de migración y remesas México. México; 2018.

[28] Davidsson, P. A General Theory of Entrepreneurship: The IndividualOpportunity Nexus. International Small Business Journal; 2004. https://doi.org/10.1177/0266242604043697

[29] Chadnda, R. A Geography of Population. New Delhi: Kalyani; 2015.

[30] Noin, D. Géographie de la population. Paris: Armand Colin; 2005.

[31] Tinley, A. La situación educativa de los Mexicanos en Estados Unidos: aprendizajes para orientar las políticas públicas de migración. México: Consejo Nacional de Población; 2015. Obtenido de http://www.conapo.gob.mx/work/models/CONAPO/migracion_intern acional/politicaspublicas/08.pdf

[32] Young, E. y Welsch, H. Major elements in entrepreneurial development in Central Mexico. Journal of Small Business Managemen; 1993; 31(4), 80-86.

[33] Girón, A. y Correa, E. Experiencia empresarial transfronteriza: migración, crisis y financiamiento. México: UNAM, Miguel Ángel Porrúa y CONAC; 2014

[34] Cacciotti, G., Hayton, J. C., Mitchell, J. R., y Giazitzoglu, A. A reconceptualization of fear of failure in entrepreneurship. Journal of Business Venturing; 2016; 31(3), 302-325. https://doi.org/10.1016/j.jbusvent.2016.02.002

[35] Eisenhardt, K. M. Building Theories from Case Study Research. Academy of Management Review. 1989; https://doi.org/10.5465/AMR.1989.4308385

[36] Hernández, R. Metodología de la investigación. México: McGrawHill; 2014.

[37] Glaser, B., y Strauss, A. The Discovery of Grounded Theory: strategies for qualitative research. New York: Aldine; 1967.

[38] Adler, P., y Adler, P. Membership Roles in Field Research. Newbury Park, CA: Sage; 1987.

[39] Baker, S., y Edwards, R. How many qualitative interviews is enough? How many qualitative interviews is enough? Expert voices and early career reflections on sampling and cases in qualitative research, 43. (R. Edwards, Ed.) Southampton, Southampton, GB: GB National Centre for Research Methods; 2012. Recuperado el 07 de febrero de 2017, de https://eprints.soton.ac.uk/336913/

[40] Brod, M., y Chistensen, T. Qualitative research and content validity: developing best practices based on science and experience. Quality of Life Research; 2009; 18, 1263-1278.

[41] Van Rijnsoever, Frank. "(I Can’t Get No) Saturation: A Simulation and Guidelines for Minimum Sample Sizes in Qualitative Research Macroeconomic Dynamics and Innovation." Innovation Studies Utrecht (ISU) Working Paper Series 2017; 12(7): 1-17. http://www.geo.uu.nl/isu/pdf/isu1505.pdf. 
[42] Vecitis, K. Young women's accounts of instrumental drug use for weight control. Deviant Behavior; 2011; 32, 451 - 474.

[43] Gioia, Dennis A., Kevin G. Corley, y Aimee L. Hamilton. Seeking Qualitative Rigor in Inductive Research: Notes on the Gioia Methodology. Organizational Research Methods; 2013; 16(1): 15-31.

[44] Pio, E. Ethnic entrepreneurship among Indian women in New Zealand: A bittersweet process. Gender, Work \& Organization; 2007; 14(5), 409-432. DOI: $10.1111 / j . I 468-0432.2007 .00358 . x$.

[45] Ho, C. China's Brain Drain is our Brain Waste, Sidney Morning Herald; 2004. https://www.smh.com.au/national/chinas-brain-drain-isour-brain-waste-20040921-gdjryi.html (accesado el 15 abril 2018).

[46] Lianos, T., y Pseiridis, A. On the occupational choices of return migrants. Entrepreneurship and Regional Development; 2009; 21(2), 155-181. https://doi.org/10.1080/08985620802176187

[47] Chrisman, J., Bauerschmidt, A., \& Hofer, C. The Determinants of New Venture Performance: An Extended Model. Entrepreneurship Theory and Practice: 1998; 23(1987), 5-29. https://doi.org/10.3905/jpe.2003.38

[48] Kshetri, N., Rojas-Torres, D., \& Cardona, M. Diaspora networks, noneconomic remittances and entrepreneurship development: evidence from some economies in Latin America. Journal of Developmental Entrepreneurship; 2015; 20(1), 1-25.

[49] Kenney, M., Breznitz, D., \& Murphree, M. Coming back home after the sun rises: Returnee entrepreneurs and growth of high tech industries. Research Policy, 42(2); 2013; 391-407. https://doi.org/10.1016/j.respol.2012.08.001

[50] Davidsson, P, y Honing, B. The role of social and human capital among nascent entrepreneurs. Journal of Business Venturing; 2003; 18(3). 301-331. 